\title{
APPLYING MURDER TECHNIQUE TO IMPROVE STUDENTS' READING COMPREHENSION OF THE SEVENTH GRADE STUDENTS OF SMP SANTO THOMAS 1 MEDAN IN THE ACADEMIC YEAR OF 2020/2021
}

\author{
Siska Ria Pandiangan, Anna Stasya Prima Sari Sinaga, Fiber Yun A. Ginting \\ Catholic University of Saint Thomas \\ Email : fiber_ginting@ust.ac.id
}

\begin{abstract}
The aim of this study is to find whetever Murder technique works effectively on improving students' reading comprehension and to describe the students' responses towards the application of Murder technique in the learning teaching processes of reading comprehension. The subject of the study in the seventh grade students of SMP Santo Thomas 1 Medan in the Academic Year of 2020/2021 consisting 32 students of class VII-A. This study was conducted by applying Classroom Action Research (henceforth CAR). The result of the test showed that the students' mean score in pre-test is 55,00 with $16 \%$ of students got $\geq 70$, in formative test is 68,13 with $38 \%$ of students got score $\geq 70$, and 83,13 in post test with $100 \%$ of students got score $\geq 70$. The qualitative data analysis showed that the students' responses after being taught by using Murder Technique are very good. The percentage students who strongly agree is $26(81 \%)$, agree is $27(84 \%)$, there is no students choose strongly disagree and disagree. It is suggested that the English teachers use Murder Technique as an alternative technique in teaching reading to the students in Junior High School in order to improve their students' reading comprehension.
\end{abstract}

Keywords: Reading Comprehension, Murder Technique, Classroom Action Research.

\section{Introduction}

Reading is one of the basic skills of language. It cannot be separated from other skills of language besides listening, speaking, and writing. Those skills must be learned all by the students. Reading also requires one to identify and understand string of words in fluid manner. It means that, students try to understand the meaning of words by words in a fast and precise way from text written. By reading do students not only get the information but also support another skills in English. Reading alwasys comes along with comprehension. Moreillon(2007:10) states that reading is making meaning from print and from visual information. But reading is not simple. Reading is an active process that requires a great deal or practice and skill. Reading printed words has different purposes. Reading comprehension is an is defined as the level of understanding of a text. This understanding comes from the interaction between the words thatare written and how the students trigger knowledge outside the text.

From the writer's observation toward class VII-A of SMP Santo Thomas 1 Medan in the Academic Year of 2020/2021 when the students were learning reading subject with the English teacher, the students still have difficulties in comprehending the contents of the text.They could not pronounce well, spell, and understand all words in any kind of the text. The students afraid when their English 


\section{KAIROS ELT JOURNAL, Vol. 4 No. 3 Desember 2020 Copyright@2020, ISSN: 2580-4278}

teacher asked them to read an English text. They were unfamiliar with many English vocabularies it made them bored and not interested in comprehending the reading text. This condition made students felt bored and were not interested in comprehending text written.

To solve the problems above, the teachers should be find a new technique to improve the students' interest and motivation in reading English texts. The English teachers are expected to find an appropriate technique to make the students understand and enjoy reading the text. Based on the explanation this research is focused on finding alternative technique in teaching reading. It is expected to makes enjoy in learning. The students should be feel fun in classroom during learning process. One of techniques that can be applied to teach reading is Mood, Understand, Recall, Detect, Elaborate and Review (henceforth,Murder) technique. Therefore, this technique requires students work in small groups, they work together to share their understanding of the text.

Some research findings have shown a good result of applying Murder technique to improve students' reading comprehension. The first research was conducted Ardika (2014) entitled "The Implementation of Murder Technique to Improve Reading Comprehension of Eleventh Grade Students at SMK Widya Wisata Graha Amlapura in Academic Year 2013/2014'. The result of the research shows that Murder technique can help students to improve their ability in reading comprehension. It was shown from the increase of mean scores of pre- test and post- test. The result of the research in the mean score of the students' pre- test in reading comprehension is 66.17 and mean score post-test is 81.76 . The second one was conducted by Ariani, Suparno, and Sulistyawati (2015) entitled "Improving Students' Reading Comprehension Using Murder Technique". The result of the research shows that Murder technique could improve students' reading comprehension. It was shown from the increase of mean scores of pre- testand posttest. The result of the research in the mean score of the students'pre- test in reading comprehension is 61.35 and mean score in post-test is 78.08.. Through Murder technique the students were more active and communicative. They had more courage to share their ideas to their partner.

Considering the results of the of the two researches the writer was interested in applying Murder technique to improve reading comprehension of the seventh grade students of SMP Santo Thomas 1 Medan in the Academic Year of 2020/2021. The writer wanted to find out whether Murder Technique was also effective to improve the students' reading comrehension and this responses to the application of Murder technique in processes of learning reading comprehension. Based on the research background the writer decides to carry out a research entitled Applying Murder Technique to Improve Students' Reading Comprehension of the Seventh Grade Students of SMP Santo Thomas 1 Medan in the Academic Year of 2020/2021.

\section{Reading}

Reading is one of the skill that should be mastered by the students. By reading students get knowledge and information or ideas from what they have read. It means, when students read a text reading they are must be able to get the important information or message from the text. Nuttal (2000:2) states that reading is a result of interaction between the writer's mind and the reader's mind. It is the 
way how to the reader tries to get the message or the intended meaning from the writer. It means, the reader get the important information by the writer's.

In addition, Grabe and Stoller (2002:9) state that reading is ability to draw the meaning from the printed page and interpret this information appropriately. It process by which people gain information and ideas from the books, letters, magazine, newspaper, journal, article, and other materials. It means, This activity ordinarily requires the readers not only to read the texts, but also understand it. Thus, it can be said that reading always comes along with comprehension. McNamara (2007:3) states that reading is an extraordinary achievement when one considers the number of levels and components that must be mastered. Consider what it takes to read a simple story.

\section{The Processes of Reading}

The process of reading is how the students to try understand the text and how the students to think what is the meaning of the text. According to Nunan (2003:70) there are three processes of reading. They are elaborated as follows: Bottom-up Model, Top-Down Model, Interactive Model.

1. Bottom-up Model

Bottom-up model fucuses on the text as the convergence of encoded messages to be deciphered. Intrusion who up hold bottom-up processing focus on how learners extract information from the printed page, and on whatever or not learners deal with letters and words in a systematic fashion.

\section{Top-Down Model}

As top-down teaching model, the learner's prior knowledge is activated, which is capable of enhancing learner's language learning, and making possible reading comprehension. In other words, in top-down model, "content schemata" are to be activated; prior knowledge plays a major role in learner's comprehension. In addition to prior knowledge as key point, top-down model is actually a whole language teaching approach, in which readers focus on the context, ang manage to construct meaning in the text.

\section{Interactive Model}

The interactive model, the last reading model of reading process, interactive approaches to reading have focused on two concepts of interaction. First, it is the interaction of two types of cognitive skills, identification and interpretation. Second, it is interaction between reader and a text. Fluent readers seem to simultaneously employ what come to be known as lower level skills that allow them to rapidly and automatically recognize words, while higher level skills allow them to comprehend and interpret a text. Lower level skills involve rapid and precise unconscious processing (automatically). In the class, we can assume that students are already relatively efficient at lower level processing.

\section{The Purposes of Reading}

According to Anderson (1992:53), there are seven goal of reading, reading for the details and facts, read for main idea, reading for sequence of organization, reading for inference, classify reading, reading for evaluate and compare the reading for the contest.

Reading for details and facts

Reading for main ideas

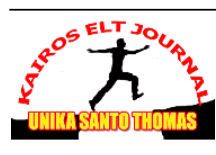


Reading to the order of organization

Reading to a conclusion

Reading to classify

Reading to evaluate

Reading to compare or contest

Based on the explenation above, the writer concluded that the purpose of reading make the person enjoy reading the text, and the purpose of reading is able to get the information, knowledge, new ideas, and the relax of the reading text.

The reader has a purpose for reading, whetever it is for entertaiment information, or research. Reading for a purpose provides motivation an important aspect of being a good reader.

Dugan (2006:140) states that all meaningful reading need a purpose. When reader understand the purpose for reading a particularly text, they can select the appropriate reading strategies that help them meet their reading goal. There are many purposes for reading, they are:

Reading for understanding

Reading to interpret

Reading for pleasure

Reading to solve problems

Reading to predict outcomes

Reading to answer specific question

Reading to form an opinion

Reading to skim for facts

Reading to discover models for your own writing

Based on the explenation above, the writer concluded that the purpose ofreading make the reader enjoy to read the text. Reading for a purpose provides motivation, and reading for get information from the text.

\section{Reading Comprehension}

Reading comprehension has always been an interesting topic to several studies.Reading comprehension is defined as the level of understanding of a text/message, vocabulary and grammatical knowledge have a big rule within this context. This understanding comes from the interaction between the words that are written and how they trigger knowledge outside the text. Snow (2002:13) states that reading comprehension is the process of simultaneously extracting and constructing meaning through interaction and involvement with written language. It consists of tree elements: the reader, the text, and the activity or purpose for reading. Martin (1991:7) states that reading comprehension requires motivation, mental framework for holding ideas, concentration and good study technique. It means that in order to be successful in reading comprehension, the reader needs to motivate himself/herself to concentrate on reading, try to form the mental frameworks for holding ideas, and the reader must have a good technique in reading.Klinger, et al (2015:2) state that reading comprehension is the process of constructing meaning by cordinating number of complex processes that include word reading, word, and word knowledge and fluency. It means that when students reading an English text they must be able to contructing what the purpose of the text. Serravallo (2010:43) states that reading comprehension is the level of understanding of a text/message, vocabulary and grammatical knowledge have a big rule within this context. This 
understanding comes from the interaction between the words that are written and how they trigger knowledge outside the text.

In conclusion reading comprehension is a complex activity where the reader can get knowledge from the text both of the information or message and new vocabularies; furthermore, to understand the text the reader need to find out the meaning the sentences that establish in the whole text. They also can retell again the information that they have read depend on their knowledge. Finally, there are a lot of benefits that the reader can get from reading. If we read a lot of books, articles, newspapers, magazines, and many things you can get a lot of knowledge and information from it.

\section{Levels of Comprehension}

Burns, Roe and Ross (1984:177-198) state that there are four levels of comprehension that must be achieved in reading comprehension. The four levels of reading comprehension are identified as follows:

Literal Reading

Reading for literal reading comprehension, which involves acquiring information that is directly stated in a selection, is important in and of itself and also a prerequisite for higher-level understanding. It means that the literal comprehensiontest the readers' ability to think within the text and consider what has been literally and explicitly stated. Recognizing stated that main ideas, details, causes and effects sequences is the basis of literal comprehension, and a thorough understanding of vocabulary, sentence meaning, and paragraph meaning is important.

Interpretive Reading

Interpretive Reading involves reading between the lines or making inferences. It process of deriving ideas that are implied rather than directly stated. Interpretive Reading consist of (1) inferring main ideas of passage in which the main ideas are not directly stated, (2) inferring cause-and-effect relationships when they are not directly stated,(3) inferring referents of pronauns, (4) inferring referents of adverbs, (5) inferring ommitted words, (6) detecting mood, (7) detecting the author's purpose in writing, and (8) drawing conclusion. It means that Interpretive Reading meaning requires the reader to go beyond the information given by the writer. The reader is required to see the significance of the data; to note the various relationships such us cause effect and relation of the part to the whole, to make comparison, to draw conclusion and inference and to make generalizations.

Critical Reading

Critical reading is evaluating written material comparing-comparing the ideas dicovered in the material with known standards and drawing conclusion about their accuracy, appropriateness, and timeliness. A critical reader must be an active reader, who always ask, look at the fact contained in the text to understand the meaning of the text itself.

Creative Reading

Creative reading involves going beyond the material presented by the autor. It requires readers to think as they read. It can also help students creatively explore their reading comprehension in which teacher should be able to be a model in teaching learning process. 


\section{Techniques in Reading Comprehension}

According to Richards and Schmidt (2002:44), reading comprehension technique is way of accessing the meaning of texts, which are employed flexibly and selectively in the course of reading. To be able to readtexts, students should have their technique. Process of reading is not a merely instant process that occurs without any strategy and sequence. There are some strategies in reading proposed by Brown (2007:306). They are:

1) identifying the purpose of reading,

2) using graphonic rules and patterns to aid in bottom up decoding,

3) using efficient silent reading techniques for relatively rapid comprehension,

4) skimming is quickly running one's eyes over a text to get the gist of it,

5) scanning is quickly going through a text to find a particular piece of information,

6) guessing when the reader does not understand,

7) analyzing vocabulary,

8) distinguishing between literal implied meaning,

9) Capitalizing ondiscourse markers to process relationships

Referred to Brown's strategies in reading help the teacher to assist students into efficient and successful readers. By applying strategies in reading the teacher and students are expected to be more organized in understanding a text. However, this research focus only on some strategies which are linear to the students' reading problems in identifying the purpose of reading, guessing meaning from context, analyzing vocabulary, using existing knowledge to make sense of new information, and asking questions about the text before, during, and after reading.

\section{Teaching Reading Comprehension}

Comprehension skills are technique readers use to retrieve information and construct meaning from a particular text. They are the thinking processes, broken down into steps that are used to comprehend. These must be taught explicitly. Three types of comprehension skills are described below: pre-reading, during reading, and post-readin (Johnson, 2008:110). Teaching reading comprehension is an activity in which the teacher guides and facilitates learning, gives a chance for the learners to learn and sets the condition for learning (Brown, 2007:7). Guidance is done by leading students to do activity in the effort of getting knowledge. The activity itself can be done by giving them tasks. However, an important point dealing with giving tasks to the students is about the consideration of technique used. A teacher should consider the best technique to be applied for a particular task or activity.

2.2.4 Principles for Teaching Reading Comprehension

There are some principles behind the teaching of reading proposed by Harmer (2001:70) They are:

Reading is not a passive skill. Understanding the meaning of the words, understanding arguments and working out for the agreement of the statements are included as active occupation in reading

Students need to be engaged with what they are reading. Harmer considers that students can get more benefit from reading if they are enaged and interested in reading text.

Students should be encouraged to respond to the content of a reading text, not just to the language. In this principle, the point is that students should have opportunities 
to respond to the message of the text and thus provoking personal engagement of the students.

Prediction is a major factor in reading. The fourth principle the students expectations and active process of reading is ready to begin when they can get the hints of the text so they can predict what's coming in the next segment a particular text.

Match the task to the topic.Choosing the good tasks for students in reading is important since it canundermine boring and inappropriate questions so the reading activitycan be more exciting and challenging for the students.

The five principles behind teaching reading propose some important points that need to be considered by the teacher in teaching reading, such as it is important to make the students engaged with and have the abilities to respond to the texts. The principles also highlight that predicting is crucial in reading since it is related to the students' active process of reading. In addition, choosing the good tasks is one of the considerations to make the reading activity be more exciting and challenging. By referring to those principles, the teacher and students can be facilitated to attain a good quality of reading process.

\subsection{Descriptive Text}

One of the texts that are taught in the level of SMP the descriptive text. Gerot and Wignell (1994: 199-222) state that descriptive text is a kind of text which is aimed to describe a particular person, place, or thing. It means that descriptive text is designed specially about a person, a place, or things. They also stated descriptive text to tell about the subject by describing its feature without including personal opinions. It also has the generic structure which is summarized as follows: a) Identification which indentifies phenomenon to be described. b) Description which describes parts, qualities, characteristics. c) The linguistic feature occurs in this text is focused on specific participants, the use of attributive and identifying process, and the use of simple present tense.

\section{Murder Technique}

Murder technique is one part of cooperative learning. Actually Murder is acronym from six words, they are M (mood), is to get positive mood from students. Step to make students is very interest with the topic of the passage and situation of students. U (understand) step to make a note what is students not understand about the passage. $\mathrm{R}$ (recall) after studying a chapter or an assignment put what being learn into own word. D (detect) is check again what do not understand about the passage and reconsider the information. E (elaborate) is elaborating the answer of the students about the topic of the passage. R (review) go back to the material once, twice or more and give an asking exercise to students. Jacob (1998:56) state that murder embodies the key cooperative learning concept. Murdertechnique can be applied with pair or groups of the students, and then each pair or group got one passage to analyze. It made the students have new idea and got new knowledge.

Hythecker et al (1988: 26-29) state that the Murder technique has many advantages. The Mood aspect of Murder technique encourages the students to relax and focus on the task. Understand helps the students to follow the author's main train by removing pressure to understand in detail. Recall helps the students to rehearse the material, to identify the main idea of each paragraph, and to transform the material into an oral mode and into the students' own words.

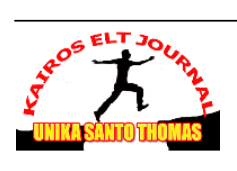


The Detect aspect encourages the students to make the summary as accurately as possible by detecting any errors or omissions. It helps the students to improve their ability in summarizing the material. Elaborate guides the students to make the information in the summary more memorable. The last is Review aspect that guides the students to produce the summary of the entire passage. In this technique, the students work in small groups. They work together to share their understanding of the text.

When writer used this technique to improve reading comprehension he must watch the procedure of the technique. Procedure bring researcher to some aspect about the technique. Dasilva (2006:187-188) states that procedure of Murder technique is The "M" in Murder stand for "mood", the first step in which the individual should attempt to find a time and place that set a positive mood. For the writer do in this procedure is to try make students happy before start teaching process and also the writer divide somes groups of the students. After the students feel relax the writer can begin the learning proces. The "U" in Murder stand for "understand", which the individual marks any information in the text that he or she does not understand by circling it, highlighting it, or simply drawing a question mark next to it. In this procedure the writer give students intructions to read their book about topic descriptive text and students try to understand about topic descriptive text. The " $R$ " in Murder stands for "recall" which the individual should attempt to paraphrase and note everything that he or she learned from the section that he or she just went over. In this procedure the writer tells the students to repeat and understand text. The " $D$ " in Murder stand for "digest/detect", suggests that the individual should go back over each topic that he or she marked earlier and reread that material in an attempt to understand that material better. In this procedure the writer suggest students to pay attention to delivery of information contain in descriptive text. The "E" in Murder stand for "expand/elaborate", suggests that the individual should go back and start asking and attempting to answer questions about the specific topics that he or she still does not understand even after completing the digest step. In this procedure the writer instructs each group to elaborate on students' understanding, students opinions, and question for each students. The " $R$ " in Murder stands for "review" all of the material that the individual actually does understand in order to refresh material in the individual's mind. In this last procedures the writer intructs the students so that each group provides a conclusion from the results of their discussion and also the writer make conclusion from the text descriptive.

The procedure helps the writer to arrange the method and use Murder in teaching reading and improving reading comprehension. Procedure of Murder technique must do step by step and chronological because there are relationships between each step on Murder technique. Each step of the technique bring a meaning which makes the students to go in the next step. If one step can finish as well, students can go in the next step. But, if the step cannot finish as well, students must stand on the step until they finish the step. 


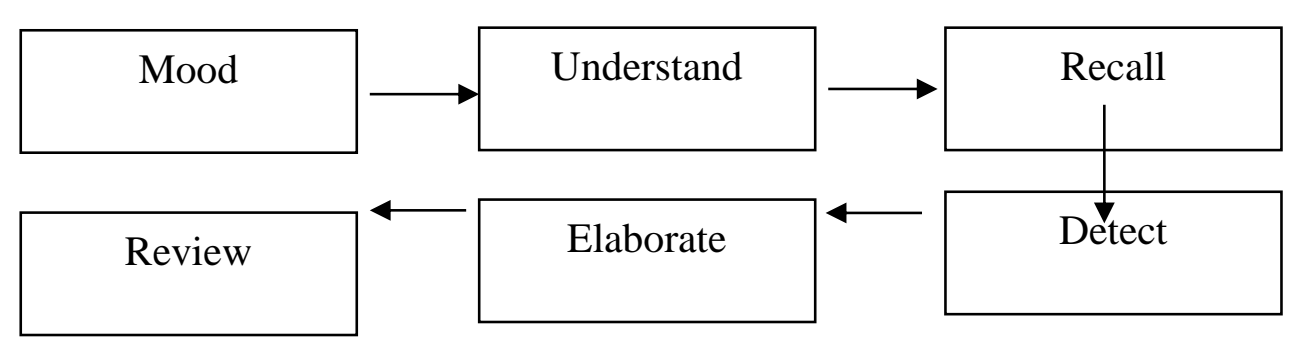

Figure 1. Procedure of Murder technique

Hythecker et al (1988: 26-29) state that There are six steps in Murder technique and each step has several purposes considered as the advantages of Murder technique. Those advantages are as follows:

Mood. It helps the students to focus on the task, to become familiar with the material and the task, and to use the study time efficiently. It also allow the students to study more effectively, because an individual will usually not be able to study effectively if he or she is in an environment that is distracting or just generally irritating.

Understand. It helps the students to follow the author's main train by removing pressure to understand in detail.

Recall. This step helps the students to rehearse the material, to identify the main idea of each paragraph, and to transform the material into an oral mode and into the students' own word.

Detect. It encourages the students to make the summary as accurately as possible by detecting any errors or omissions. It helps the students to improve their ability in summarizing the material.

Elaborate : To make students easier for memorize, students are ask to elaborate the information. The types of elaborations include the following; connecting with another things that students have been study before, making link between the topic of the section with students' real-life, learners add any information that is not include in the text.

Review : The last step is review. It will do when all of part have been completed to discuss. The learners are asked to summarize as the output or the result of the technique.

\section{Research Method}

The Research Design

This is Classroom Action Research (henceforth,CAR). Burns (2010:5) states that action research is a reflective process that aims to solve a particular teaching-learning problem that has been identified. CARcerried out by the teacher in order to solve problem or to find answer toward context-specific issues. In order to do action research, it was necessary to carry out a rigorous study in which the problem has to be clearly specified, an action plan has to be described and carried out, and finally an evaluation had to be contemplated in order to show if decisions taken were the adequate ones. It means that action research came from the problems of the teacher when he or she taught his or her students. Action research helped the teacher to evaluate and get solution of his or her problems in teaching. Therefore, the teacher could improve their ways to teach the students. For example at Budi 
Mulia some students could not understand about reading as well, so the researcher tried to solve their problem with a technique on reading. In purpose to improve the students reading comprehension and make the students more understand about reading.

McKay (2006:29) states that action research has tree major characteristics: it is carried out by practitioners (i.e., classroom teachers), it is collaborative, and it is aimed at changing things. It means that the action research can be done by a teacher in a classroom with the help of other teachers to discuss what and how to improve the classroom activities so that the students' achievement will be better.

The writer together with the English teacher took the decisions of determining the research subject, looked into problems happening in the field and implemented the research design. Besides being collaborative, this research is also focused on improving the teaching and learning of reading. It would be described qualitatively and supported by quantitative data that would be gained from the students' reading test score. qualitative data is pre-test, formative test, and post-test and quantitative data is fielt note, questionnaire and observation sheet. quantitative is In this research the writer used qualitative data and quantitative data.

The Place and Time of the Study

The study was conducted at SMP Santo Thomas 1 Medan which is located at JL. S. Parman Budi No. 109 Medan Petisah. There are two reasons why the writer chooses the school as the location of the research. The are: 1) Based on the observation that was done by the writer, it is needed to improve the reading comprehension of the seventh grade students of SMP Santo Thomas 1 Medan in the Academic Year of 2020/2021 through Murder technique. 2) Based on the writer's knowledge there has never been any research about improving students' reading comprehension through Murder technique. This research was conducted in August 2020.

\section{The Subject of the Study}

There are eight classes of the seventh grade students of SMP Santo Thomas 1 Medan, namely, VII-A until VII-G. The writer took Class VII-A as the research subject. In class VII-A there are 32 students (15 females and 17males).

\section{Kind of Data}

There are two kinds of data in this study. They are quantitative data and qualitative data. Qualitative data were obtained from the observbation teacher and students. Quantitative data were obtained from the students' reading test before, during and after the learning teaching process. In this data collection, the writer needs a collaborator. A collaborator in classroom action research was the teacher of English at the seventh grade students of SMP Santo Thomas 1 Medan in the Academic Year of 2020/2021.

The Intruments for Collecting Data

To collect the data of the research, the writer used some instruments of research. It was used to get some information as quantitatively of characteristic and objective of variable. There are some instruments that the researcher used on the research. 


\section{Data Analysis and Discussion}

\section{The Data Analysis}

There are two types of data which were anlyzed to find out the result out of the research findings. The are quantitative and qualitative data. The analysis of both data are elaborated as follows.

Quantitative Data

The quantitative data was taken from the test result of students, namely pretest before treatment, formative test after cycle one, posttest after cycle two. The complete result of the students' score in every test can be seen from the table and histogram of score interval and frequency.

\section{Conlussions and Suggestions \\ Conclusions}

After analyzing and discussing the data, the writer draws the following conclusions as follows:

Murder technique can improve students' reading comprehension. It was found out that the students achievement of reading comprehension on descriptive text improved from pre-test to post-test after Mureder technique was applied. The students' total mean score in pre-test is 55.00 , the formative test is 68.13 , and posttest is 83.13. meanwhile, the students' score percentage who passed Mastery Minimum Criteria (Kriteria Ketuntasan Minimal) from pre-test is $16 \%$, the formative test is $38 \%$, and post-test is $100 \%$, the students' score and percentage continuously increased in each test. Therefore, it is concluded that Murder technique can improve students reading comprehension on descriptive text.

Based on the results of field notes, observation sheets, the students felt and response that Murder technique is very effective and appropriate to help them improve their reading comprehension on descriptive text.

\section{Suggestions}

Based on the study result, the writer proposes some suggestions as follows:

1. The English teachers should be more active, creative and innovative to select the teaching technique to deliver their material. The English teachers must be able to find a good technique teaching learning to make students' interest in learnig English, especially in learning reading comprehension. The English teachers should teach reading comprehension by applying Murder technique because this tecgnique can make the create a pleasant and challenging learning atmosphere thus students feel more motivated and interested in learnig reading.

2. The students are suggested to keep on motivating and improving their reading comprehension more intensively; for instance, motivate themselves to learn English texts more seriously, not only in the classroom but also in outside the classroom. Then to enrich their knowledge they have to read a lot of books. They could use Murder technique as one of alternatives to help them improve their reading comprehension.

3. For other writers who are going to conduct a classroom action research, it is suggested to use more reading passage in teaching learning process and hopefully it can be used as a reference and guidance in conducting the same study obtaining better result. The research of this study is expected to able to 
provide valuable information how to applying Murder technique to improve students' reading comprehension.

\section{BIBLIOGRAHY}

Anderson, D. 1992. Assesing Reading. Chicago: American Library Association.

Ardika, I. W. 2014. The Implementation of Murder Technique to Improve Reading Comprehension of the Eleventh Grade Students at SMK Widya Wisata Graha Amlapura in Academic Year 2013/2014. A Sarjana's Thesis, Faculty of Teacher Training and Education: Mahasaraswati Denpasar University.

Ariani, G. Suparno, and Sulistyawati, H. 2015. Improving Students' Reading Comprehension Using Murder Technique. Journal of Literature, Linguistics, and English Teaching (JoLLiET), 2(1), 24-29.

Burns, A. 2010. Doing Action Research in English Language Teaching: A Guide for Practitioners. New York: Routledge.

Burns, P. C., Roe, B. D., and Ross, E. P. 1984. Teaching Reading in Today's Elementary Schools (Third Edition). Boston: Houghton Mifflin Company.

Brown, H. D. 2007. Teaching by Principles. New York: Longman.

Dasilva, I. 2006. Cooprerative Learning and second Language Teaching. Cambridge: Cambridge University Press.

Dugan, C. 2006. Practice with Purpose: Standards-Based Reading Comprehension Secondary Level.Huntington Beach: Beach City Press.

Gerot, L. \& Wignell, P. 1994. Making Sense on Functional Grammar. Sidney: Gerd Stabler.

Grabe,W., \& Stoller, F, L. 2002. Teaching and Researching Reading. London: Pearson Education.

Hadjar, I. 1999. Dasar-Dasar Metodologi Penelitian Kuantitatif dalam Pendidikan. Jakarta: Raja Grafindo Persada.

Harmer, J. 2001. How to Teach English. Cambridge: Longman.

Heilman, A, et al. 1988. The Principles and The Practices of Teaching Reading. Ohio: Merill Publishing Co.

Hythecker, V.I., et al. 1988. An Analysis of the Process Influencing in the Structure Dyadic Learning Environment. Journal of Educational Psychology, 23(1),23-37.

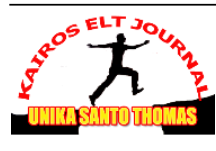


Jacob, G.M., 1998. Cooperative Learning: A Source Book of Lesson Plan Teacher Education. Singapore: SEAMEO Regional Language Centre.

Johnson, P., A. Teaching Reading and Writing ( A Guidebook for Tutoring and Remediating Students). New York: Rowman \& Littlefield Publishers.

Klinger, K. J., Boardman, A., \& Vaughn, S. 2015. Teaching Reading Comprehension to Students with Learning Difficulties $\left(2^{\text {nd }} E d\right)$. New York: The Guilford Press.

Martin, D. 1991. How to be A Successful Students. California: Marin Trails Publishing LLC.

McCafferty, S.G., et al. 2006. Cooperative Learning and Second Language Teaching. Cambridge: Cambridge Language Education.

McKay, S. L. 2006. Researching Second Language Classrooms. London: Lawrence Erlbaum Associates.

McNamara, K. 2007. Reading Comprehension Strategies. New York: Lawrence Erlbaum Associates.

Moreillon, J. 2007. Collaborative Strategies for Teaching Reading Comprehension. Chicago: American Library Association.

Nunan, D. 2003. Practical English Language Teaching. New York: McGraw Hill.

Nuttal, C. 2002. Teaching Reading Skill in A Foreign Language. Oxford: Macmilland Heineman.

Richards, J., C. \& Richard, S. 2002. Language Teaching and Applied Linguistics. London: Routledge.

Serravallo, J. 2010. Teaching Reading in Small Groups. New York: Greenwood Publishing Group, Inc.

Simon, B., V. 2010. Improving students' Reading Comprehension Through Murder Technique . Jakarta: Visimedia.

Snow, C. 2002. Reading for Understanding toward An R\&D Program in Reading Comprehension. Santa Monica: RAND.

Tovani, C. 2000. I Read It, but I Don't Get It: Comprehension Strategies for Adolescent Readers. Newington: Stenhouse Publisher.

White, et al. 2012. Understanding Reading Comprehension in High School. Kingston: Queen university. 